\title{
PENGARUH HARA, KUALITAS PRODUK DAN KUALITAS PELAYANAN TERHADAP KEPUTUSAN PEMBELIAN (STUDI KASUS PADA WARUNG SATE KLATAK PAK PONG BANTUL)
}

\author{
Muhammad Hendri Adhitama \\ hendriadhitamaa@gmail.com \\ Universitas Ahmad Dahlan \\ Sukardi \\ sukardi_feuad@yahoo.com \\ Universitas Ahmad Dahlan
}

\begin{abstract}
ABSTRAK
This study aims to analyze the influences of prices, quality of products and services on purchasing decision in Pak Pong Klatak Satay Culinary in Bantul. The subjects of this research were customers of Pak Pong Klatak Satay Culinary in Bantul. The population of the study were people who purchased products of Pak Pong Klatak Satay Culinary in Bantul. The samples were determined by accidental sampling method by total of 80 respondents. Data were collected by giving a list of questions / questionnaires to respondents dealing with prices, products quality as well as services quality and how they influence the customers decision in purchasing the products. This study used a multiple linear regression analysis technique. The researcher tested the hypothesis using $\mathrm{T}$ test and $\mathrm{F}$ test. The test results showed that prices have a positive but insignificant influence, products quality has a negative and insignificant influence. Meanwhile, services quality has a positive and significant influence. Prices, products and services quality contribute to a simultaneously positive and significant influence upon customer's purchasing decision as the significant value of 0,000 is smaller than 0,5 . The prices variables, products quality and services quality are able to explain the purchasing decision variable in Pak Pong's klatak satay culinary at $35 \%$ and the remaining $65 \%$ explained by other variables not included in the study.
\end{abstract}

Keywords: Price, Product Quality, Services Quality and Purchasing Decision.

\section{PENDAHULUAN}

Pada zaman sekarang ini banyak perubahan dan kemajuan yang terjadi pada dunia bisnis, baik dunia bisnis produk ataupun jasa. Banyak konsumen pada masa ini lebih memilih sesuatu yang dirasa lebih modern daripada memilih sesuatu yang dikenal tradisional. Hal tersebut sering terjadi pada produk kuliner tradisional yang sering dianggap kurang menarik atau sudah jadul sehingga minat konsumen untuk membeli cenderung kurang.

Namun, produk kuliner tradisional di Yogyakarta tidak mengalami ketatnya persaingan dengan produk kuliner modern yang banyak terdapat di cafe-cafe dan juga restoran di Yogyakarta ini, banyak anak muda, keluarga dan juga wisatawan luar daerah yang masih tertarik dengan adanya produk kuliner tradisional yang dijajakan oleh pelaku bisnis masakan tradisional.

Hal yang dapat kita jadikan contoh tentang kuliner tradisonal yang masih eksis hingga sekarang ialah makanan khas Bantul yaitu sate klatak. Pelaku bisnis sate klatak yang masih eksis hingga sekarang seperti kita ketahui ialah warung sate klatak Pak Pong yang terletak di 
Jalan Sultan Agung Jejeran Bantul, dengan konsep masakan tradisional olahan daging kambing dapat memikat dayabeli konsumen.

Dengan mendirikan warung dikawasan sentra olahan daging kambing dengan masakan khasnya sate klatak, warung sate klatak Pak Pong bisa dibilang menjadi warung sate yang paling laris dibandingkan dengan pesaing lainnya yang juga menjajakan makanan yang sama, dengan harga yang sedikit lebih mahal dibanding warung lainnya tidak menjadikan warung sate klatak Pak Pong sepi pembeli, dengan mengandalkan cita rasa yang enak menjadikan daya tarik tersendiri bagi para pembelinya yang tidak hanya berasal dari kota Bantul melainkan seluruh daerah di Indonesia yang kebetulan berkunjung di Bantul atau sengaja datang ke Bantul hanya untuk mencicipi olahan yang disediakan di warung sate klatak Pak Pong dan juga ditunjang oleh letak warung yang berada dipingir jalan dan mempunyai fasilitas warung yang lebih nyaman dan lebih luas daripada pesaing lainnya menjadikan warung tersebut ramai pembeli.

Tujuan dari penelitian ini di antaranya: 1) untuk mengetahui pengaruh harga terhadap keputusan pembelian dalam produk di warung sate klatak Pak Pong, 2) untuk mengetahui pengaruh kualitas produk terhadap keputusan pembelian dalam produk di warung sate klatak Pak Pong, 3) untuk mengetahui pengaruh kualitas pelayanan terhadap keputusan pembelian dalam produk di warung sate klatak Pak Pong dan 4) untuk mengetahui pengaruh harga, kualitas produk dan kualitas pelayanan secara bersama-sama terhadap keputusan pembelian dalam produk di warung sate klatak Pak Pong.

\section{REVIEW LITERATUR DAN HIPOTESIS}

\section{Landasan Teori}

1. Harga

Harga adalah jumlah uang yang dibutuhkan untuk mendapatkan sejumlah kombinasi dari produk dan pelayanannya (Swastha, 2002).

\section{Kualitas Produk}

Kotler (2004) mengemukakan bahwa kualitas produk adalah kemampuan suatu produk untuk melakukan fungsi-fungsinya. Kemampuan itu meliputi daya tahan, kehandalaan, ketelitian yang dihasilkan, kemudahan dioprasikan dan diperbaiki, dan atribut lain yang berharga pada produk secara keseluruhan.

3. Kualitas Pelayanan

Kualitas pelayanan merupakan tingkat keunggulan yang diharapkan dan pengendalian atas hal tersebut untuk memenuhi harapan konsumen (Rangkuti, 2006).

4. Keputusan Pembelian

Kotler (2009) mengungkapkan keputusan untuk membeli yang diambil oleh konsumen itu merupakan kumpulan dari sejumlah keputusan. Setiap keputusan membeli mempunyai suatu struktur yang terdiri dari beberapa komponen, antara lain: 1) keputusan tentang jenis produk, 2) keputusan tentang bentuk produk, 3) keputusan tentang merek, merek mana yang akan dipilih konsumen untuk dibeli, 4) keputusan tentang penjualnya, produk tersebut dibeli dimana dan pada toko apa, 5) keputusan tentang jumlah produk, banyaknya produk yang akan dibeli, 6) keputusan tentang waktu pembelian dan 7) keputusan tentang cara pembayaran. 


\section{Penelitian Terdahulu}

1. Analisis pengaruh harga, kualitas pelayanan, promosi dan kepercayaan terhadap kepuasan konsumen dengan keputusan berkunjung sebagai variabel intervening di hotel Amanda Hills Bandungan. Oleh Susilo H, AT Haryono, M Mukery (2018). Penelitian dilakukan hotel Amanda Hills Bandungan dengan teknik pengambilan data dengan kuisioner, menggunakan metode analisis linear berganda dan menghasilkan kesimpulan sebagai berikut: 1) terdapat pengaruh harga terhadap keputusan bekunjung konsumen di Amanda Hills Hotel Bandungan, 2) terdapat pengaruh kualitas pelayanan terhadap keputusan bekunjung konsumen di Amanda Hills Hotel Bandungan, 3) terdapat pengaruh promosi terhadap keputusan bekunjung konsumen di Amanda Hills Hotel Bandungan dan 4) terdapat pengaruh kepercayaan terhadap keputusan bekunjung konsumen di Amanda Hills Hotel.

2. Pengaruh kualitas produk, harga dan lokasi terhadap keputusan pembelian di Powernoise Store (studi kasus pada konsumen Powernoise Store Malang). Oleh Rofiq, M Hufron (2018). Penelitian dilakukan di Powernoise Store Malang dengan teknik pengambilan data dengan kuisioner menggunakan metode analisis regresi berganda dan menghasilkan kesimpulan sebagai berikut: 1) pada uji $\mathrm{F}$, menunjukkan bahwa semua variabel independen yaitu kualitas produk, harga dan lokasi secara simultan berpengaruh signifikan terhadap keputusan pembelian di PowerNoise Store, 2) pada Uji t, dapat dilihat bahwa variabel kualitas produk secara parsial berpengaruh positif dan signifikan terhadap keputusan pembelian, kemudian pada variabel harga secara parsial berpengaruh positif dan signifikan terhadap keputusan pembelian. Selanjutnya pada variabel lokasi secara parsial berpengaruh positif dan tidak signifikan terhadap keputusan pembelian.

\section{Hipotesis}

H1: Harga berpengaruh positif dan signifikan terhadap keputusan pembelian dalam pembelian produk di sate klatak Pak Pong.

$\mathrm{H} 2$ : Kualitas produk berpengaruh positif dan signifikan terhadap keputusan pembelian dalam pembelian produk di sate klatak Pak Pong.

H3: Kualitas pelayanan berpengaruh positif dan signifikan terhadap keputusan pembelian dalam pembelian produk di sate klatak Pak Pong.

H4: Harga, kualitas produk dan kualitas pelayanan berpengaruh positif dan signifikan secara bersama-sama terhadap keputusan pembelian dalam pembelian produk di sate klatak Pak Pong.

\section{METODE PENELITIAN}

\section{Populasi dan Sampel}

Populasi adalah wilayah generalisasi yang terdiri atas objek atau subjek yang mempunyai kualitas dan karakteristik tertentu yang ditetapkan oleh peneliti untuk dipelajari dan kemudian ditarik kesimpulannya (Sugiyono, 2015).

Populasi dalam penelitian ini adalah konsumen atau orang-orang yang pernah melakukan pembelian produk di warung sate klatak Pak Pong Jalan Sultan Agung, Brajan, Wonokromo, Pleret, Bantul. Hal itu diharapakan agar hasil yang didapatkan dalam penilitian ini bisa lebih efektif serta sesuai dengan apa yang peneliti inginkan.

Sampel adalah bagian dari jumlah dan karakteristik yang dimiliki oleh 
populasi tersebut. Pengambilan sampel dilakukan dengan pertimbangan bahwa populasi yang ada sangat besar jumlahnya, sehingga tidak memungkinkan untuk meneliti seluruh populasi yang ada.

Menurut Sugiyono (2012) dalam Mumu et.al., (2015) sampel adalah bagian dari jumlah karakteristik yang dimiliki oleh populasi tersebut. Adapun pada penelitian ini, teknik pengambilan sampel yang digunakan adalah Accidental Sampling terhadap para konsumen yang melakukan pembelian di warung sate klatak Pak Pong Bantul. Teknik pengambilan sampel secara Accidental Sampling yaitu pengambilan sampel secara sembarang (kapanpun dan dimanapun) asal memenuhi syarat sebagai sampel dari populasi tertentu.

Pada penelitian ini jumlah populasi tidak diketahui, oleh karena itu jumlah sampel dalam penelitian ini ditentukan berdasarkan pendapat dari Roscue dalam buku Research Methods For Business (1982) dikuti dalam Sugiyono (2015) memberikan saran-saran tentang ukuran sampel untuk penelitian seperti berikut ini:

1. Ukuran sampel yang layak dalam penelitian adalah antara 30 sampai dengan 500.

2. Bila sampel dibagi dalam kategori (misalnya: pria- wanita, pegawai negeri-swasta dan lain-lain), maka jumlah anggota sampel setiap kategori minimal 30 .

3. Bila dalam penelitian akan melakukan analisis dengan multivariate (korelasi atau regresi ganda misalnya), maka jumlah anggota sampel minimal 10 kali dari jumlah variabel yang diteliti. Misalnya variabel penelitiannya ada 5 (independen+dependen), maka jumlah anggota sampel adalah $10 \times 5=50$.

Jadi dalam penelitian ini, peneliti memilih poin pertama dari pendapat Roscue dalam menentukan ukuran sampel, sehingga jumlah sampel yang diambil pada penelitian ini adalah 80 .

\section{Definisi Operasional}

1. Variabel Independen

a. Harga. Indikator yang digunakan untuk menilai harga menurut Tjiptono (2008) yaitu keterjangkauan harga produk, kesesuaian harga dengan kualitas produk, daya saing harga produk dan kesesuaian harga dengan manfaat produk.

b. Kualitas Produk. Indikator yang digunakan untuk menilai kualitas produk menurut Kotlet (2009) yaitu bentuk, fitur, kualitas kinerja, kesan kualitas, ketahanan, keandalan, kemudahan perbaikan, gaya dan desain.

c. Kualitas Pelayanan. Indikator yang digunakan untuk menilai kualitas pelayanan menurut Tjiptono (2008) yaitu bukti langsung, keandalan, daya tanggap, jaminan dan empati.

2. Variabel Dependen

Variabel dependen yang digunakan dalam penelitian ini adalah keputusan pembelian. Indikator yang digunakan untuk menilai keputusan pembelian yaitu pengenalan masalah, pencarian informasi, evaluasi alternatif, keputusan pembelian dan perilaku pasca pembelian.

\section{Uji Instrumen}

\section{Uji Validitas}

Uji validitas digunakan untuk mengukur sah atau valid tidaknya suatu kuesioner. Suatu kuesioner dikatakan valid jika pertanyaan dan kuesioner mampu untuk mengungkap sesuatu yang akan diukur oleh kuesioner tersebut. Untuk menguji validitas dalam penelitian ini dapat menggunakan analisis faktor konfirmatori atau Confirmatory Factor Analysis (CFA).

Validitas menunjukan sejauh mana suatu pengukur itu mengukur apa yang ingin diukur. Hasil penelitian yang valid terjadi apabila terdapat 
kesamaan antara data yang terkumpul dengan data yang sesungguhnya terjadi pada objek yang diteliti. Validitas berarti instrumen yang dipilih dapat digunakan untuk mengukur apa yang seharusnya diukur (Sugiyono, 2015).

Dalam pengambilan keputusan untuk menguji validitas indikatornya adalah:

1. Jika $\mathrm{r}$ hitung positif serta $\mathrm{r}$ hitung > 0,05 , maka butir atau variabel tersebut valid.

2. Jika $r$ hitung tidak positif dan $r$ hitung $<0,05$, maka butir atau variabel tersebut tidak valid.

\section{Uji Reliabilitas}

Uji reliabilitas digunakan untuk mengetahui konsistensi alat ukur, apakah alat pengukur yang digunakan dapat diandalkan dan tetap konsisten jika pengukuran tersebut diulang. Suatu kuesioner dikatakan reliabel atau handal jika jawaban seseorang terhadap pernyataan adalah konsisten atau stabil konsisten atau stabil dari waktu ke waktu (Ghozali, 2006).

Pengukuran reliabilitas dapat dilakukan dengan One Shot atau pengukuran sekali saja, adapun cara yang digunakan adalah dengan menggunakan uji statistik Cronbach Alpha $(\alpha)$. Suatu kontruk atau variabel dikatakan reliabel jika memberikan nilai Cronbach Alpha $>0.60$.

\section{Teknik Analisis Data}

1. Analisis Regresi Berganda

Menurut Simamora (2005) regresi berganda (multiple regression) merupakan metode analisis yang tepat manakala masalah riset meliputi sebuah variabel dependen, datanya metrik, diasumsikan berhubungan dengan dua atau lebih variabel independen. Caranya adalah dengan memprediksi perubahan variabel dependen melalui perubahan variabelvariabel independen. Aturan yang dipakai adalah jumlah kuadrat terkecil (least squares).

Dengan metode ini kita dapat memprediksi besarnya variabel dependen. Misalnya, apabila model atau rumusnya sudah ditemukan, kepuasan dapat diprediksi berdasarkan intensitas harga, kualitas produk dan kualitas pelayanan. Persamaan regresi dalam penelitian ini adalah:

$\mathrm{Y}=\mathrm{a}+\mathrm{b} 1 \mathrm{X} 1+\mathrm{b} 2 \mathrm{X} 2+\mathrm{b} 3 \mathrm{X} 3$

Keterangan:

$\mathrm{Y}=$ Keputusan pembelian

$\alpha=$ Konstanta

$\mathrm{X} 1$ = Harga

$\mathrm{X} 2=$ Kualitas Produk

X3 = Kualitas Pelayanan

b1, b2, b3= koefisien regresi variabel independen

\section{Uji Hipotesis}

1. Uji Parsial (Uji T)

Uji statistik $t$ menunjukkan seberapa jauh pengaruh harga, kualitas produk dan kualitas pelayanan secara individual dalam menerangkan keputusan pembelian (Ghozali, 2006).

\section{Uji Simultan (Uji F)}

Uji $\mathrm{F}$ digunakan untuk menguji hipotesis nol bahwa koefisien determinasi majemuk dalam populasi, R2 sama dengan nol. Uji signifikansi meliputi pengujian signifikansi persamaan regresi secara keseluruhan serta koefisien regresi parsial spesifik. Uji keseluruhan dapat dilakukan dengan menggunakan statistik $\mathrm{F}$.

Statistik uji ini mengikuti distribusi $\mathrm{F}$ dengan derajat kebebasan $\mathrm{k}$ dan (n- k- 1) (Malhotra, 2006) dalam (Sutrisni, 2010). Jika hipotesis nol keseluruhan ditolak, satu atau lebih koefisien regresi majemuk populasi mempunyai nilai tak sama dengan 0 .

Dalam uji $F$ kesimpulan yang diambil adalah dengan melihat signifikasi $(\alpha)$ dengan ketentuan: 
$\mathrm{H} 0=\alpha>5 \%$ (tidak ada pengaruh yang signifikan).

$\mathrm{Ha}=\alpha<5 \%$ (ada pengaruh yang signifikan).

\section{Uji Koefisien Determinasi}

Koefisien determinasi $\left(\mathrm{R}^{2}\right)$ pada intinya digunakan untuk mengukur seberapa jauh kemampuan model dalam menerangkan variasi variable dependen. Nilai koefisien determinasi adalah antar nol sampai satu $\left(0<\mathrm{R}^{2}<1\right)$. Nilai $R^{2}$ yang kecil berarti kemampuan variabel-variabel independen dalam menjelaskan variasi variabel dependen amat terbatas. Nilai yang mendekati satu berarti variabel-variabel independen memberikan hampir semua informasi yang dibutuhkan untuk memprediksi variasi variabel dependen (Ghozali, 2011).

Secara umum koefisien determinasi untuk data silang (crossection) relatif rendah karena adanya variasi yang besar antara masing-masing pengamatan, sedangkan untuk data runtun waktu (time series) biasanya memepunyai nilai koefisien determinasi yang tinggi. Selain itu, koefisien determinasi (R2) dipergunakan untuk mengetahui prosentase perubahan variabel tidak bebas (Y) yang disebabkan oleh variabel bebas $(\mathrm{X})$.

\section{HASIL PENELITIAN DAN PEMBAHASAN}

\section{Hasil Analisis Responden}

Karakteristik berdasarkan Asal daerah/provinsi

\begin{tabular}{|l|c|c|}
\hline \multicolumn{1}{|c|}{ Asal Daerah/Provinsi } & Frekuensi & Persentase \\
\hline Bantul & 23 & $29 \%$ \\
\hline Gunung Kidul & 3 & $4 \%$ \\
\hline Kulon Progo & 6 & $7 \%$ \\
\hline Sleman & 8 & $10 \%$ \\
\hline Aceh & 1 & $1 \%$ \\
\hline Jawa Barat & 5 & $6 \%$ \\
\hline Jawa Tengah & 8 & $10 \%$ \\
\hline Jawa Timur & 1 & $1 \%$ \\
\hline Jakarta & 4 & $5 \%$ \\
\hline Sumatera Selatan & 4 & $5 \%$ \\
\hline Maluku & 2 & $3 \%$ \\
\hline Papua & 1 & $1 \%$ \\
\hline Yogyakarta & 14 & $18 \%$ \\
\hline Jumlah & $\mathbf{8 0}$ & $\mathbf{1 0 0} \%$ \\
\hline
\end{tabular}

Berdasarkan data di atas maka diperoleh data karakteristik responden berdasarkan asal daerah/provinsi sebagai berikut:

a. Responden asal daerah/provinsi Bantul berjumlah 23 orang atau sebesar 29\% dari total 80 responden.

b. Responden asal daerah/provinsi Gunung Kidul berjumlah 3 orang atau sebesar 4\% dari total 80 responden.

c. Responden asal daerah/provinsi Kuon Progo berjumlah 6 orang atau sebesar $7 \%$ dari total 80 responden.

d. Responden asal daerah/provinsi Sleman berjumlah 8 orang atau sebesar $10 \%$ dari total 80 responden.

e. Responden asal daerah/provinsi Aceh berjumlah 1 orang atau sebesar $1 \%$ dari total 80 responden.

f. Responden asal daerah/provinsi Jawa Barat berjumlah 5 orang atau sebesar $6 \%$ dari total 80 responden.

g. Responden asal daerah/provinsi Jawa Tengah berjumlah 8 orang atau sebesar $10 \%$ dari total 80 responden.

h. Responden asal daerah/provinsi Jawa Timur berjumlah 1 orang atau sebesar $1 \%$ dari total 80 responden. 
i. Responden asal daerah/provinsi Jakarta berjumlah 4 orang atau sebesar 5\% dari total 80 responden.

j. Responden asal daerah/provinsi Sumatera Selatan berjumlah 4 orang atau sebesar $5 \%$ dari total 80 responden.

k. Responden asal daerah/provinsi Maluku berjumlah 2 orang atau sebesar $3 \%$ dari total 80 responden.

1. Responden asal daerah/provinsi Papua berjumlah 1 orang atau sebesar $1 \%$ dari total 80 responden.

$\mathrm{m}$. Responden asal daerah/provinsi Yogyakarta berjumlah 14 orang atau sebesar $18 \%$ dari total 80 responden.

Karakteristik Berdasarkan Jenis Kelamin

\begin{tabular}{|c|c|c|}
\hline Jenis Kelamin & Frekuensi & Persentase \\
\hline Laki-laki & 45 & $56,25 \%$ \\
\hline Perempuan & 35 & $43,75 \%$ \\
\hline Jumlah & $\mathbf{8 0}$ & $\mathbf{1 0 0} \%$ \\
\hline
\end{tabular}

Berdasarkan data di atas maka diperoleh data karakteristik responden berdasarkan jenis kelamin sebagai berikut:

a. Responden yang berjenis kelamin laki laki berjumlah 45 orang atau sebesar $56,25 \%$ dari total 80 responden.

b. Responden yang berjenis kelamin perempuan berjumlah 35 orang atau sebesar $43,75 \%$ dari total 80 responden

\begin{tabular}{|c|c|c|}
\multicolumn{3}{|c}{ Karakteristik Berdasarkan Usia } \\
\hline Usia & Frekuensi & Persentase \\
\hline$<20$ tahun & 17 & $21,3 \%$ \\
\hline $21-25$ tahun & 31 & $38,8 \%$ \\
\hline $26-30$ tahun & 22 & $27,5 \%$ \\
\hline $31-35$ tahun & 6 & $7,5 \%$ \\
\hline $36-40$ tahun & 4 & $5 \%$ \\
\hline$>41$ tahun & 0 & $0 \%$ \\
\hline Jumlah & $\mathbf{8 0}$ & $\mathbf{1 0 0} \%$ \\
\hline
\end{tabular}

Berdasarkan data di atas maka diperoleh data karakteristik responden berdasarkan usia sebagai berikut:

a. Responden yang berusia $<20$ tahun berjumlah 17 orang atau sebesar $21,5 \%$ dari total 80 responden.

b. Responden yang berusia 21-25 tahun berjumlah 31 orang atau sebesar $38,8 \%$ dari total 80 responden.

c. Responden yang berusia 26-30 tahun berjumlah 22 orang atau sebesar $27,5 \%$ dari total 80 responden. d. Responden yang berusia 31-35 tahun berjumlah 6 orang atau sebesar 7,5\% dari total 80 responden.

e. Responden yang berusia 36-40 tahun berjumlah 4 orang atau sebesar 5\% dari total 80 responden.

f. Responden yang berusia > 41 tahun berjumlah 0 orang atau sebesar $0 \%$ dari total 80 responden.

Karakteristik Berdasarkan Pekerjaan
\begin{tabular}{|c|c|c|}
\hline Pekerjaan & Frekuensi & Persentase \\
\hline Pelajar/Mahasiswa & 37 & $46,3 \%$ \\
\hline Wiraswasta & 10 & $12,5 \%$ \\
\hline Karyawan Swasta & 11 & $13,5 \%$ \\
\hline PNS & 5 & $6,3 \%$ \\
\hline Polisi & 2 & $2,5 \%$ \\
\hline TNI & 4 & $5 \%$ \\
\hline Buruh & 7 & $8,8 \%$ \\
\hline Dan Lain-lain & 4 & $5 \%$ \\
\hline Jumlah & 80 & $100 \%$ \\
\hline
\end{tabular}

Berdasarkan data di atas maka diperoleh data karakteristik responden berdasarkan jenis pekerjaan sebagai berikut:

a. Responden yang bekerja sabagai pelajar/mahasiswa berjumlah 37 orang atau sebesar $46,3 \%$ dari total 80 responden.

b. Responden yang bekerja sabagai Wiraswasta berjumlah 10 orang atau sebesar $12,5 \%$ dari total 80 responden.

c. Responden yang bekerja sabagai karyawan swasta berjumlah 11 orang atau sebesar $13,8 \%$ dari total 80 responden.

d. Responden yang bekerja sabagai PNS berjumlah 5 orang atau sebesar 6,3\% dari total 80 responden.

e. Responden yang bekerja sabagai Polisi berjumlah 2 orang atau sebesar 2,5\% dari total 80 responden.

f. Responden yang bekerja sabagai TNI berjumlah 4 orang atau sebesar 5\% dari total 80 responden.

g. Responden yang bekerja sabagai Buruh berjumlah 7 orang atau sebesar $8,8 \%$ dari total 80 responden.

h. Responden yang bekerja diluar item yang ditanyakan berjumlah 4 orang atau sebesar 5\% dari total 80 responden. 
Karakteristik Berdasarkan Pendapatan Per Bulan

\begin{tabular}{|c|c|c|}
\hline Pendapatan Per Bulan & Frekuensi & Persentase \\
\hline 1-2 Juta & 33 & $41,3 \%$ \\
\hline 2,1-3 Juta & 19 & $23,8 \%$ \\
\hline 3,1-4 Juta & 16 & $20 \%$ \\
\hline 4,1-5 Juta & 6 & $7,5 \%$ \\
\hline >5,1 Juta & 6 & $7,5 \%$ \\
\hline Jumlah & $\mathbf{8 0}$ & $\mathbf{1 0 0} \%$ \\
\hline
\end{tabular}

Berdasarkan data di atas, maka diperoleh karakteristik responden berdasarkan pendapatan per bulan sebagai berikut:

a. Responden yang memiliki pendapatan Rp.1.000.000-Rp.2000.000 berjumlah 33 orang atau sebesar $41,3 \%$ dari total 80 responden.

b. Responden yang memiliki pendapatan Rp.2.100.000-Rp.3.000.000 berjumlah 19 orang atau sebesar $23,8 \%$ dari total 80responden.

c. Responden yang memiliki pendapatan Rp.3.100.000 -Rp.4.000.000 berjumlah 16 orang atau sebesar $20 \%$ dari total 80 responden.

d. Responden yang memiliki pendapatan Rp.4.100.000 -Rp.5.000.000 berjumlah 6 orang atau sebesar $7,5 \%$ dari total 80 responden.

e. Responden yang memiliki pendapatan $>$ Rp.5.100.000 berjumlah 6 orang atau sebesar $7,5 \%$ dari total 80 responden.

\section{Hasil Penelitian}

1. Hasil Uji Validitas

a. Variabel Harga

Hasil Uji Validitas Variabel Harga

\begin{tabular}{|c|c|c|}
\hline $\begin{array}{c}\text { No. } \\
\text { Item }\end{array}$ & Factor loading & Keterangan \\
\hline 1 & 0,917 & Valid \\
\hline 2 & 0,945 & Valid \\
\hline 3 & 0,889 & Valid \\
\hline 4 & 0,787 & Valid \\
\hline
\end{tabular}

Dari hasil di atas menunjukkan bahwa factor loading $>0,5$, jadi keempat item pernyataan di atas dinyatakan valid, jadi untuk semua item pernyataan indikator variabel harga dinyatakan valid. b. Variabel Kualitas Produk Tahap 1

Hasil Uji Validitas Variabel Kualitas Produk Tahap 1

\begin{tabular}{|c|c|c|c|}
\hline \multirow{2}{*}{$\begin{array}{c}\text { No. } \\
\text { Item }\end{array}$} & \multicolumn{2}{|c|}{ Component } & \multirow{2}{*}{ Keterangan } \\
\cline { 2 - 3 } & 1 & 2 & \\
\hline 1 & 0,832 & $-0,302$ & Valid \\
\hline 2 & 0,857 & $-0,348$ & Valid \\
\hline 3 & 0,913 & 0,003 & Valid \\
\hline 4 & 0,383 & 0,760 & Tidak valid \\
\hline 5 & 0,480 & 0,718 & Tidak valid \\
\hline 6 & 0,649 & $-0,434$ & Valid \\
\hline 7 & 0,804 & 0,239 & Valid \\
\hline
\end{tabular}

Dari hasil di atas menunjukkan bahwa factor loading masih ada yang di bawah 0,5, jadi hasil yang tidak valid harus dihilangkan, berdasarkan hasil Anti-image Matrices nilai terendah ada di item kualitas produk nomer empat dengan nilai 0,638. Jadi item kualitas produk nomer empat dan lima harus dihilangkan.

Tahap 2

Hasil Uji Validitas Variabel Kualitas Produk Tahap 2

\begin{tabular}{|c|c|c|c|}
\hline \multirow{2}{*}{$\begin{array}{c}\text { No. } \\
\text { Item }\end{array}$} & \multicolumn{2}{|c|}{ Component } & \multirow{2}{*}{ Keterangan } \\
\cline { 2 - 3 } & 1 & 2 & \\
\hline 1 & 0,856 & $-0,213$ & Valid \\
\hline 2 & 0,891 & $-0,206$ & Valid \\
\hline 3 & 0,905 & 0,046 & Valid \\
\hline 5 & 0,420 & 0,827 & Tidak valid \\
\hline 6 & 0,678 & $-0,470$ & Valid \\
\hline 7 & 0,785 & 0,377 & Valid \\
\hline
\end{tabular}

Dari hasil diatas menunjukkan bahwa factor loading masih ada yang di bawah 0,5 , jadi hasil yang tidak valid harus dihilangkan, berdasarkan hasil Anti-image Matrices nilai terendah ada di item kualitas produk nomer lima dengan nilai 0,646. Jadi item kualitas produk nomer lima harus dihilangkan.

Tahap 3

Hasil Uji Validitas Variabel Kualitas Produk Tahap 3

\begin{tabular}{|c|c|c|}
\hline $\begin{array}{c}\text { No. } \\
\text { Item }\end{array}$ & Factor loading & Keterangan \\
\hline 1 & 0,872 & Valid \\
\hline 2 & 0,910 & Valid \\
\hline 3 & 0,897 & Valid \\
\hline 6 & 0,712 & Valid \\
\hline 7 & 0,753 & Valid \\
\hline
\end{tabular}


Dari hasi di atas menunjukkan bahwa tabel sudah membentuk satu komponen (component matrix), jadi dari ketujuh item setelah dihilangkan item yang tidak valid yaitu item nomer empat dan lima, maka diketahui terdapat lima item yang valid yaitu item nomer satu, dua, tiga, enam dan tujuh, karena hasilnya menunjukkan bahwa Factor loading >0,5, sehingga tabel membentuk satu komponen.

c. Variabel Kualitas Pelayanan

Hasil Uji Validitas Variabel Kualitas Pelayanan

\begin{tabular}{|c|c|c|}
\hline $\begin{array}{c}\text { No. } \\
\text { Item }\end{array}$ & Factor loading & Keterangan \\
\hline 1 & 0,813 & Valid \\
\hline 2 & 0,853 & Valid \\
\hline 3 & 0,909 & Valid \\
\hline 4 & 0,723 & Valid \\
\hline 5 & 0,871 & Valid \\
\hline
\end{tabular}

Dari hasil di atas menunjukkan bahwa factor loading $>0,5$, jadi kelima item pernyataan di atas dinyatakan valid, jadi untuk semua item pernyataan indikator variabel kualitas pelayanan dinyatakan valid.

d. Variabel Keputusan Pembelian

Hasil Uji Validitas Variabel Keputusan Pembelian

\begin{tabular}{|c|c|c|}
\hline $\begin{array}{c}\text { No. } \\
\text { Item }\end{array}$ & Factor loading & Keterangan \\
\hline 1 & 0,856 & Valid \\
\hline 2 & 0,851 & Valid \\
\hline 3 & 0,903 & Valid \\
\hline 4 & 0,776 & Valid \\
\hline 5 & 0,889 & Valid \\
\hline
\end{tabular}

Dari hasil di atas menunjukkan bahwa factor loading $>0,5$, jadi ke lima item pernyataan di atas dinyatakan valid, jadi untuk semua item pernyataan indikator variabel keputusan pembelian dinyatakan valid.

2. Hasil Uji Reliabilitas

Hasil Uji Reliabilitas

\begin{tabular}{|l|l|c|c|}
\hline No & Variabel & $\begin{array}{l}\text { Cronnbach } \\
\text { alpha }\end{array}$ & Keterangan \\
\hline 1 & Harga & 0,908 & Reliabel \\
\hline 2 & Kualitas Pelayanan & 0,887 & Reliabel \\
\hline 3 & Kualitas Produk & 0,890 & Reliabel \\
\hline 4 & KeputusanPembelian & 0,903 & Reliabel \\
\hline
\end{tabular}

Dari tabel di atas, maka hasil dari uji reliabilitas dapat dijelaskan bahwa dari item pertanyaan masing-masing variabel dinyatakan reliabel. Hal ini ditunjukan dari nilai Cronbach Alpha > 0,60 dari masing-masing variabel.

3. Hasil Uji Regresi Linier Berganda Hasil Uji Regresi Linier Berganda (Koefisien Regresi)

\begin{tabular}{|c|c|c|}
\hline \multirow{2}{*}{ Model } & $\begin{array}{c}\text { Unstandardized } \\
\text { Coefficients }\end{array}$ & \multirow{2}{*}{ Sig. } \\
\cline { 2 - 2 } & $\mathbf{B}$ & \\
\hline 1 (Constant) & 1.649 & 0.007 \\
\hline Harga & 0.046 & 0.653 \\
\hline Kualitas Produk & -0.017 & 0.880 \\
\hline Kualitas Pelayanan & 0.525 & 0.000 \\
\hline
\end{tabular}

Berdasarkan analisis data di atas diperoleh persamaan sebagai berikut: $\mathrm{Y}=1,649+0,046 \mathrm{X} 1-0,017 \mathrm{X} 2+$ $0,525 \mathrm{X} 3$

Dari hasil persamaan regresi linier berganda tersebut, dapat diinterprestasikan sebagai berikut:

$\mathrm{Y}=$ variabel yang nilainya akan diprediksi oleh variabel independen. Dalam penelitian ini, yang menjadi variabel dependen adalah keputusan pembelian, yang nilainya diprediksi oleh variabel harga, kualitas produk, dan kualitas pelayanan.

$\mathrm{a}=1,649$, merupakan nilai konstanta, dengan demikian nilai konstanta ini menunjukkan besarnya nilai variabel keputusan pembelian jika variabel independen sama dengan nol.

b1 $=0,046$, artinya variabel harga berpengaruh positif terhadap keputusan pembelian dan apabila variabel harga meningkat, maka nilai keputusan pembelian juga meningkat. Semakin tinggi kenaikan nilai variabel harga akan semakin tinggi mempengaruhi keputu san pembelian.

b2 $=-0,017$, artinya variabel kualitas produk berpengaruh negatif terhadap keputusan pembelian. Hal ini menunjukkan bahwa, apabila kualitas produk mengalami kenaikan maka keputusan pembelian akan mengalami penurunan. Semakin tinggi kenaikan nilai variabel kualitas produk akan 
semakin rendah mempengaruhi keputusan pembelian.

b3 $=0,525$, artinya variabel kualitas pelayanan berpengaruh positif terhadap keputusan pembelian dan apabila variabel kualitas pelayanan meningkat, maka nilai keputusan pembelian juga meningkat. Semakin tinggi nilai kualitas pembelian, maka semakin tinggi juga akan mempengaruhi nilai keputusan pembelian .

\section{Hasil Uji Parsial (Uji T)}

\begin{tabular}{|c|c|}
\multicolumn{2}{|c|}{ Hasil uji signifikansi parsial (uji t) } \\
\hline Variabel & Hasil Uji Signifikan \\
\hline Harga & 0.653 \\
\hline Kualitas Produk & 0.889 \\
\hline Kualitas Pelayanan & 0.000 \\
\hline
\end{tabular}

Berdasarkan tabel di atas, maka hasil uji $t$ pada penelitian ini dapat dijelaskan sebagai berikut:

a. Variabel Harga

Dilihat dari nilai sig hitung < alpha $(0,05)$ pada tabel di atas nilai sig hitung yang diperoleh sebesar 0.653 . Hal ini menunjukkan bahwa nilai sig hitung $0,653>0,05$, maka dapat disimpulkan bahwa hipotesis HO diterima dan Ha ditolak yang berarti bahwa tidak terdapat pengaruh positif dan signifikan antara variabel harga (X1) terhadap keputusan pembelian di warung sate klatak Pak Pong (Y).

b. Variabel Kualitas Produk

Dilihat dari nilai sig hitung < alpha $(0,05)$ pada tabel di atas nilai sig hitung yang diperoleh sebesar 0.889 . Hal ini menunjukkan bahwa nilai sig hitung $0,889>0,05$, maka dapat disimpulkan bahwa hipotesis HO diterima dan Ha ditolak yang berarti bahwa tidak terdapat pengaruh positif dan signifikan antara variabel kualitas produk (X2) terhadap keputusan pembelian sate klatak Pak Pong (Y). c. Variabel Kualitas Pelayanan

Dilihat dari nilai sig hitung < alpha $(0,05)$ pada tabel di atas nilai sig hitung yang diperoleh sebesar 0.000. Hal ini menunjukkan bahwa nilai sig hitung $0,000<0,05$, maka dapat disimpulkan bahwa hipotesis $\mathrm{Ha}$ diterima dan $\mathrm{HO}$ ditolak yang berarti bahwa terdapat pengaruh positif dan signifikan antara variabel kualitas pelayanan (X3) terhadap keputusan pembelian di warung sate klatak Pak Pong (Y).

5. Hasil Uji Simultan (Uji F)

\begin{tabular}{|c|c|c|}
\multicolumn{2}{|c|}{ Hasil uji signifikansi simultan (uji F) } \\
\hline Model & F & Sig \\
\hline Regression & 13.643 & 0.000 \\
\hline Residual & - & - \\
\hline Total & 13.643 & 0.000 \\
\hline
\end{tabular}

Berdasarkan hasil uji simultan dari tabel di atas ditunjukan bahwa $\mathrm{F}$ hitung sebesar 13,643 dan pada uji $F$ di atas didapatkan dengan taraf signifikansi 0,05 (sig $0,000<0,05$ ), dapat disimpulkan bahwa faktor Harga (X1), Kualitas Produk (X2) dan Kualitas Pelayanan (X3) secara bersama-sama memiliki pengaruh signifikan terhadap Keputusan Pembelian di warung sate klatak Pak Pong (Y).

6. Hasil Uji Koefisien Determinasi Hasil uji koefisien determinasi (R2)

\begin{tabular}{|c|l|l|l|l|}
\hline Model & \multicolumn{1}{|c|}{$\mathrm{R}$} & $\mathrm{R}$ Square & $\begin{array}{c}\text { Adjusted R } \\
\text { Square }\end{array}$ & $\begin{array}{c}\text { Std. Error of } \\
\text { The Estimate }\end{array}$ \\
\hline 1 & .592 & .350 & .324 & .57838 \\
\hline
\end{tabular}

Pada tabel di atas dapat dilihat bahwa nilai R2 adalah sebesar 0,350. Hal ini dapat diartikan bahwa variabel independen harga (X1), kualitas produk (X2) dan kualitas pelayanan (X3) dapat menjelaskan variabel dependen keputusan pembelian di warung sate klatak Pak Pong (Y) sebesar 35,0 \%, sisanya $65,0 \%$ diterangkan oleh faktor lain yang tidak diteliti. 


\section{Pembahasan}

1. Pengaruh Harga Terhadap Keputusan Pembelian.

Pernyataan hipotesis pertama bahwa variabel harga (X1) tidak berpengaruh positif dan signifikan terhadap keputusan pembelian sate klatak Pak Pong (Y). Hal ini bisa ditunjukan dengan nilai signifikansi $(\mathrm{P}$ Value) sebesar 0,653>0,05. Dengan demikian dapat disimpulkan bahwa variabel harga (X1) tidak berpengaruh positif dan signifikan terhadap keputusan pembelian di warung sate klatak Pak Pong (Y).

Hasil penelitian ini menunjukan keputusan pembelian di warung sate klatak Pak Pong tidak begitu bergantung pada harga, konsumen lebih cenderung melakukan pembelian karena faktor lain, seperti untuk wisata kuliner atau sekedar untuk memenuhi kebutuhan tersier karena warung sate klatak Pak Pong termasuk kuliner yang dijadikan rujukan oleh wisatawan luar kota dan harga yang dibilang lumayan mahal. Hasil ini tidak sesuai dengan penelitian yang dilakukan oleh Rofiq A, M Hufron (2018) bahwa harga berpengaruh signifikan terhadap keputusan pembelian.

2. Pengaruh Kualitas Produk Terhadap Keputusan Pembelian.

Pernyataan hipotesis kedua bahwa variabel kualitas produk (X2) tidak berpengaruh positif dan tidak signifikan terhadap keputusan pembelian di warung sate klatak Pak Pong (Y). Hal ini bisa ditunjukan dengan nilai signifikan (P Value) sebesar 0,889 >0,05. Dengan demikian dapat disimpulkan bahwa variabel kualitas produk (X2) tidak berpengaruh signifikan terhadap keputusan pembelian di warung sate klatak Pak Pong (Y).

Hasil ini tidak sesuai dengan penelitian yang dilakukan oleh Putra
Rahmad Sanyomai (2017) bahwa kualitas produk berpengaruh signifikan terhadap keputusan pembelian. Ketidak signifikan ini dapat dipengaruhi oleh beberapa hal salah satunya yaitu pada indikator kualitas produk khususnya pada kuesioner pertanyaan poin tiga, yaitu porsi sate klatak Pak Pong sesuai dengan yang diinginkan pembeli, hal tersebut belum sesuai dengan yang diharapkan pembeli karena porsi sate klatak warung lain banyak yang lebih banyak dari porsi warung sate klatak Pak Pong.

3. Pengaruh Kualitas Pelayanan Terhadap Keputusan Pembelian.

Pernyataan hipotesis ketiga bahwa variabel kualitas pelayanan (X3) berpengaruh positif dan signifikan terhadap keputusan pembelian di warung sate klatak Pak Pong (Y). Hal ini bisa ditunjukan dengan nilai signifikan sebesar $0,000<0,05$. Dengan demikian dapat disimpulkan bahwa variabel kualitas pelayanan (X3) berpengaruh positif dan signifikan terhadap keputusan pembelian (Y).

Hal ini menunjukan bahwa kualitas pelayanan mempengaruhi keputusan pembelian di warung sate klatak Pak Pong. Hasil ini sesuai dengan penelitian yang dilakukan oleh Susilo H, A.T Haryono, M Mukery (2018) bahwa kualitas pelayanan berpengaruh signifikan terhadap keputusan pembelian. Kesignifikaan ini dipengaruhi karena pelayanan di warung sate klatak Pak Pong lebih unggul dibandingkan pesaingnya, dari segi tempat makan yang luas dan fasilitas yang memadahi serta keramahan para pelayan menjadikan pelayanan di warung ini banyak diminati pembeli. 
4. Pengaruh Harga, Kualitas Produk dan Kualitas Pelayanan Terhadap Keputusan Pembelian.

Berdasarkan hasil uji simultan menunjukkan bahwa nilai F- hitung sebesar 13,643 dengan signifikansi sebesar 0,000. Apabila dibandingkan dengan tingkat signifikansi yang diharapkan yaitu $5 \%$ berarti signifikansi F- hitung lebih kecil dari tingkat signifikan yang diharapkan $(0 \%$ $<5 \%$ ). Dengan demikian harga, kualitas produk dan kualitas pelayanan secara simultan berpengaruh signifikan terhadap keputusan pembelian .

\section{KESIMPULAN DAN SARAN}

\section{Kesimpulan}

1. Variabel harga berpengaruh positif dan tidak signifikan terhadap keputusan pembelian di warung sate klatak Pak Pong dengan nilai signifikan sebesar 0,653. Hal ini menunjukkan bahwa harga sate klatak Pak Pong tidak terlalu menjadi faktor utama atau mempengaruhi keputusan pembelian oleh konsumen warung sate klatak Pak Pong.

2. Variabel kualitas produk berpengaruh tidak positif dan tidak signifikan terhadap keputusan pembelian di warung sate klatak Pak Pong dengan nilai signifikan sebesar 0,889 . Hal ini menunjukkan bahwa kualitas produk warung sate klatak Pak Pong tidak terlalu menjadi faktor utama atau mempengaruhi keputusan pembelian oleh konsumen warung sate klatak Pak Pong.

3. Variabel kualitas pelayanan berpengaruh positif dan signifikan terhadap keputusan pembelian di warung sate klatak Pak Pong dengan nilai signifikan sebesar 0,000 . Hal ini menunjukkan bahwa kualitas pelayanan warung sate klatak Pak Pong menjadi faktor utama dan mempengaruhi keputusan pembelian oleh konsumen di warung sate klatak Pak Pong.

4. Hasil olah data uji $\mathrm{F}$, ketiga variabel independen berpengaruh positif dan signifikan terhadap variabel dependen. Sehingga dapat ditarik kesimpulan bahwa variabel harga (X1), kualitas produk (X2) dan Kualitas Pelayanan (X3) secara bersama-sama memiliki pengaruh yang positif dan signifikan terhadap keputusan pembelian di warung sate klatak Pak Pong (Y).

\section{Saran}

1. Saran Bagi Warung Sate Klatak Pak Pong.

a. Hasil penelitian menunjukkan bahwa variabel harga dan kualitas produk tidak berpengaruh positif dan signifikan terhadap keputusan pembelian. Oleh karena itu diharapkan untuk meningkatkan produk sehingga produk dapat memuaskan konsumen, sehingga berpengaruh pada harga yang tidak terlalu dipermasalahkan oleh pelanggan atau harga produk sebanding dengan kualitas produk. Supaya konsumen tidak hanya memandang sate klatak Pak Pong dari nama besarnya tetapi juga dari kualitas yang diberikannya.

b. Bagi warung sate klatak Pak Pong sebaiknya mempertahankan kualitas pelayanannya karena dilihat dari kesimpulan bahwa kualitas pelayanan berpengaruh positif dan signifikan terhadap keputusan pembelian. Bisa dengan cara menambah fasilitas yang sudah ada, contoh: wifi, supaya konsumen semakin betah dalam menunggu orderan jadi dan juga menjadi daya tarik lebih dibandingkan dengan warung lain yang belum memiliki fasilitas sekomplit sate klatak Pak Pong. 
2. Saran Bagi Konsumen

a. Jadilah konsumen yang bijak dalam membeli suatu kebutuhan bukan karena keinginan tetapi sesuatu yang dibutuhkan, karena di zaman modern ini masyarakat sangat konsumtif yang hanya mementingkan prestise dan gengsi. Jangan jadikan hal tersebut sebagai kebiasaan, belilah produk yang sesuai dengan kebutuhan anda dan mempunyai kualitas yang sesuai dengan harga yang ditawarkan.

3. Bagi Peneliti Selanjutnya

a. Dapat memperbaiki keterbatasan yang ada dalam penelitian ini dan memperbanyak jumlah sampel untuk mendapatkan hasil yang menyeluruh atau mendekati sempurna karena semakin banyak sampel, maka semakin nyata pula kesimpulan yang dihasilkan.

b. Dapat memperluas atau menyempurnakan variabel-variabel yang ada dalam penelitian ini agar faktor keputusan pembelian lebih bervariatif dan diharapkan bisa memberi manfaat lebih luas bagi yang diteliti dan juga bagi peneliti selanjutnya.

c. Jadikan penelitian ini sebagai bekal dalam penelitian selanjutnya, ambil yang baik/bagus dan sempurnakanlah yang dikira belum baik/bagus.

\section{DAFTAR PUSTAKA}

Ghozali, Imam. (2006). Aplikasi Analisis Multivariate dengan Program SPSS. Semarang: Badan Penerbit Universitas Diponegoro.

Ghozali, Iman. (2011). Aplikasi Analisis Multivariate dengan Program IBM
SPSS. Semarang: Badan Penerbit Universitas Diponegoro.

Kotler, Philip dan Gary Armstrong. (2004). Dasar-Dasar Pemasaran. Edisi Kesembilan. Jakarta: Indeks.

Kotler, Philip dan Kevin Lane Keller. (2009). Manajemen Pemasaran. Edisi Kedua Belas. Terjemahan Benyamin Molan. Klaten: PT Macanan Jaya Cermerlang.

Mumu et al., (2015). Analisis Gaya Kepemimpinan, Kompensasi, Pendidikan dan Pelatihan Terhadap Kinerja Karyawan Pada PT. Hasjrat Multifinance Manado. Jurnal EMBA. Vol. 3 No. 3 (September), hal. 1287- 1297.

Putra, Rahmad Sanyomai. (2017). Pengaruh Citra Merek, Kualitas Produk, Harga Dan Promosi Terhadap Keputusan Pembelian Smartphone Di Kota Yogyakarta. Skripsi. Yogyakarta: Universitas Ahmad Dahlan.

Rangkuti, Freddy. (2006). Measuring Customer Satisfaction. Jakarta: Penerbit Gramedia.

Rofiq A dan Hufron M. (2018). Pengaruh kualitas produk, harga dan lokasi terhadap keputusan pembelian di Powernoise Store Malang (studi kasus pada konsumen Powernoise Store).

Simamora, Bilson. (2005). Analisis Multivariat Pemasaran. Jakarta: PT. Gramedia Pustaka Utama.

Sugiyono. (2015). Metode Penelitian Pendidikan. Cetakan Keduapuluh Satu. Bandung: Alfabeta.

Susilo, H, dkk. (2018). Analisis pengaruh harga, kualitas pelayanan, promosi, dan kepercayaan terhadap kepuasan konsumen dengan keputusan berkunjung sebagai variabel intervening di Hotel Amanda Hills Bandungan. Journal of Management. 
Sutrisni. (2010). Analisis Pengaruh Kualitas Produk, Kualitas Pelayanan, Desain Produk, Harga dan Kepercayaan Terhadap Loyalitas Pelanggan Indosat IM3 Pada Mahasiswa Fakultas Ekonomi Universitas Diponegoro Semarang. Skripsi. Semarang: Universitas Diponegoro Semarang.

Swasta dan Irawan. (2002). Manajemen Pemasaran Modern. Yogyakarta: Liberty.

Tjiptono, Fandy. (2008). Strategi Pemasaran. Edisi Ketiga. Yogyakarta: Andi. 